\title{
THE EFFECT OF FOLIAR APPLICATION OF AMINO ACIDS ON THEIR CONTENT AND COMPOSITION IN WINTER WHEAT GRAIN
}

Rūta DROMANTIENĖ. Institute of Agroecosystems and Soil Sciences, Faculty of Agronomy, Vytautas Magnus University. K. Donelaičio g. 58, LT-44248 Kaunas, Lithuania, ruta.dromantietiene@vdu.lt (corresponding author)

Irena PRANCKIETIENE். Institute of Agroecosystems and Soil Sciences, Faculty of Agronomy, Vytautas Magnus University. K. Donelaičio g. 58, LT-44248 Kaunas, Lithuania. irena.pranckietiene@vdu.lt

Gvidas ŠIDLAUSKAS. Institute of Agroecosystems and Soil Sciences, Faculty of Agronomy, Vytautas Magnus University. K. Donelaičio g. 58, LT-44248 Kaunas, Lithuania. sgvidas@gmail.com

Vita SMALSTIENE. Institute of Agroecosystems and Soil Sciences, Faculty of Agronomy, Vytautas Magnus University. K. Donelaičio g. 58, LT-44248 Kaunas, Lithuania. vita.smalstiene@vdu.lt

Field experiments were carried out at the Experimental Station of Vytautas Magnus University $\left(54^{\circ} 52^{\prime}\right.$ N, $23^{\circ} 49^{\prime}$ E) in Lithuania. Winter wheat was grown on the background of $\mathrm{N}_{150} \mathrm{P}_{90} \mathrm{~K}_{90}$ mineral fertilization and was additionally foliar-fertilized with different concentrations of amino acid solutions (0.5-3.0\%) at stem elongation and heading stages. The study was aimed to establish protein content as well as quantitative and qualitative distribution of amino acids in winter wheat grain as influenced by fertilization with different concentrations of amino acids.

Experimental evidence showed that solutions with different concentrations of amino acids applied at winter wheat stem elongation and heading stages increased grain protein content and total amino acids contents. Plants, fertilized with amino acids solutions at stem elongation stage accumulated higher protein content by on average $4.8 \%$, at heading stage by $4.5 \%$ compared with the grain protein content of plants that had not received amino acids fertilization. The total amino acids content in winter wheat grain in response to amino acids applied at stem elongation stage increased by on average $2.0 \mathrm{~g} \mathrm{~kg}^{-1}$, at heading stage by $5.3 \mathrm{~g} \mathrm{~kg}^{-1}$. Nonessential and essential amino acids content in winter wheat grain was significantly increased by 2.5 and $3.0 \%$ amino acids solutions, applied at stem elongation stage by and $0.5,1.0,1.5 \%$ amino acids solutions applied at heading stage. Winter wheat fertilization with amino acids solutions at stem elongation stage mostly increased the content of glutamic acid, at heading stage mostly increased the contents of glutamic, aspartic, valine, isoleucine, leucine, phenylalanine, methionine, threonine and lysine acids.

Keywords: amino acids, fertilization, protein, winter wheat

\section{INTRODUCTION}

Winter wheat is the most common cereal crop cultivated in World. Agronomic practices encompassing the use of promising cultivars, foliar fertilization with biostimulants, such as humic acid and amino acids, as well as nitrogen fertilizer levels have a profound effect on wheat crop growth, grain yield and chemical composition, especially under unfavorable for plant growth and development environmental conditions (Shewry, 2007; Kandil et al., 2016).

Amino acids are considered as precursors and constituents of proteins (Shewry, 2007), which are important for stimulation of cell growth and root system (De Lucia, Vecchietti, 2012; Du Jardin, 2015). They contain both acid and basic groups and act as buffers, which help to maintain a favourable $\mathrm{pH}$ value within the plant cell (Tegeder and Rentsch, 2010). Moreover, amino acids are well known biostimulants which exert positive effects on plant growth, yield and significantly mitigate the damage caused by abiotic stresses (Azimi et al., 2013; Calvo et al., 2014). Amino acids are a good source of nitrogen, once these are quickly incorporated into the plant metabolism (Mendes et al., 2016). Amino acids induce yield increases and enhanced crop quality increasing plant tolerance to and recovery from abiotic stresses, facilitating nutrient assimilation, translocation and use enhancing quality attributes of produce (Liang et al., 2013; Calvo et al., 2014), promoting the processes of plant respiration, photosynthesis and protein synthesis (Sadak et al., 2015). Amino acids are further used for the synthesis of enzymes and proteins mainly involved in building up plant architecture and the different components of the photosynthetic machinery (Calvo et al., 2014). Plants foliar spraying with amino acids rapidly changing nutrients deficiencies due to its being readily absorbed and directly utilized to synthesis proteins (Kandil et al., 2016).

Grain proteins contain a rather high proportion of amino acids, mostly glutamic acid and proline, which are found in gluten composition. Amino acids composition determines not only grain nutritional qualities but also physical and functional protein characteristics (Tegeder and Rentsch, 2010; Penas et al., 2013 Le et al., 2016;). Biological protein value is determined by amino acids composition and essential amino acids ratio to other amino acids. Most often protein needs of a human body are met by the protein standard - essential amino acids which account for $31.4 \%$ of the total amino acids content (Friedman, 
1996). Animals, including humans, can only produce about half of the 20 common amino acids needed for life; the rest known as essential amino acids - must be obtained via diet (Zhu et al., 2010; Le et al., 2016; Wang et al., 2017). The limited Lysine and Methionine contents reduce the nutritional values of these crop plants to 50-75\%, compared to those of a diet possessing balanced levels of essential amino acids. This limitation in essential amino acids can lead to nonspecific signs of protein deficiencies in humans, such as lowered resistance to diseases, decreased blood proteins and retarded mental and physical development in young children (Zhu et al., 2010; Galili and Amir, 2013; Le et al., 2016).

Grain protein generally lacks in essential amino acids, while other amino acids are present in excess. This reduces the nutritional value of grain (Khan et al., 2014). Despite the knowledge about the positive effect of amino acid application on plants, most of the studies were carried out with products composed of a set of amino acids, and there is little information regarding the isolated effect of these amino acids on plants and amino acids content in grain (Colla et al., 2015). The study was aimed to establish protein content and quantitative and qualitative distribution of amino acids in winter wheat grain as influenced by foliar fertilization with different concentrations of amino acids.

\section{MATERIALS AND METHODS}

Field place and conditions. A field experiment with a winter wheat cultivar 'Širvinta 1' was set up at Vytautas Magnus University's Experimental Station $\left(54^{\circ} 52^{\prime} \mathrm{N}, 23^{\circ} 49^{\prime} \mathrm{E}\right)$ in Lithuania. The experiment was conducted in three consecutive years on a medium textured Cal(ca)ri-Epihypogleyic Luvisol (IUSS-WRB, 2014) with a $\mathrm{pH}_{\mathrm{KCl}}$ of 6.8-7.5, phosphorus $\left(\mathrm{P}_{2} \mathrm{O}_{5}\right)$ content of $255-355 \mathrm{mg} \mathrm{kg}^{-1}$ soil, potassium $\left(\mathrm{K}_{2} \mathrm{O}\right)$ content of $130-152 \mathrm{mg} \mathrm{kg}^{-1}$ soil and a total nitrogen (N) content of $0.12-0.14 \%$. The two-factor experiment plots were arranged in a randomized block design with four replications. Factor A is concentration of amino acids; Factor B is fertilization timing.

Experimental design. The winter wheat background fertilization: granulated superphosphate $\left(\mathrm{P}_{90}\right)$ and potassium chloride $\left(\mathrm{K}_{90}\right)$ were applied in the autumn, before sowing; urea $\left(\mathrm{N}_{90}\right)$ was applied in the spring after the winter wheat resumption of vegetation $(\mathrm{BBCH} 22-24)$. Additionally, the winter wheat was foliar fertilized with liquid amide nitrogen (N$\mathrm{NH}_{2}-18.5 \%$ ) fertilizer $\mathrm{N}_{30}$ at the stem elongation stage (BBCH 32-35), $\mathrm{N}_{20}$ at the heading stage (BBCH 51-56). Fertilizer treatments : 1) control-without amino acids, 2) $0.5 \%$ concentrations of amino acids, 3) $1.0 \%$ concentrations of amino acids, 4) $1.5 \%$ concentrations of amino acids, 5) $2.0 \%$ concentrations of amino acids, 6) $2.5 \%$ concentrations of amino acids, 7) $3.0 \%$ concentrations of amino acids. 2-7 Amino acids were foliar at the stem elongation stage (BBCH 32-35) and at the heading stage (BBCH 51-56). The content of free amino acids in the product is $22 \%$. The qualitative composition of amino acids present in the fertilizer $\left(\mathrm{g} \mathrm{kg}^{-1}\right)$ : aspartic (40.7), threonine (21.51), serine (60.91), glutamic (37.78), glycine (35.49), alanine (24.60), valine (28.68), methionine (4.10), isoleucine (18.24), leucine (40.56), tyrosine (1.83), phenylalanine (25.38), histidine (1.63), lysine (2.77) and arginine (33.27). The total volume of solution was $2001 \mathrm{ha}^{-1}$.

Experimental and analytical methods. The soil $\mathrm{pH}_{\mathrm{KCl}}$ was measured in $1 \mathrm{~N} \mathrm{KCl}$ extraction using a potentiometric method, organic carbon $(\mathrm{C})$ by a Tyurin method, available phosphorus $\left(\mathrm{P}_{2} \mathrm{O}_{5}\right)$ and potassium $\left(\mathrm{K}_{2} \mathrm{O}\right)$ by an Egner-RiehmDomingo (A-L) method, mineral nitrogen $\left(\mathrm{N}_{\min }\right)$ by $1 \mathrm{~N} \mathrm{KCl}$ extraction, total nitrogen was measured by a Kjeldahl method. Protein content $(\%)$ of grains was calculated by multiplying nitrogen content determined by a Kjeldahl method by a coefficient of 5.7 (ISO 712:1998). Amino acids were separated by an ion exchange chromatography and were detected photometrically at a $570 \mathrm{~nm}$ wave length range using ninhydrin reagent in the reaction.

Statistical analysis. All experimental data were processed by an analysis of variance (ANOVA). Correlation coefficients and relationships between the indicators tested were determined using the software STATISTICA 7 (Hill, Levicki, 2005). The symbols $*$ and letters used in this paper represent statistically significant differences at $95 \%$ probability level $(\mathrm{P}<0.05)$. The extreme point was calculated according to the formula: $\mathrm{y}=-\mathrm{b} / 2 \mathrm{c}$ (Hill, Levicki, 2005).

\section{RESULTS AND DISCUSSION}

Protein content in grain determines wheat nutritional value and technological characteristics; therefore it is one of the key grain quality indicators (Nuttall et al., 2017). The data showed a positive effect of additional foliar fertilizing with amino acids on protein content in the winter wheat grain at all growth stages investigated (Table 1). The positive effect of higher amino acids concentrations (1.5-3.0\%) stood out at stem elongation stage. These concentrations increased grain protein content by 0.6 to 0.8 percentage points.

Table 1. The effect of amino acids applied at winter wheat on grain protein $(\%)$ content

\begin{tabular}{|l|c|c|}
\hline \multirow{2}{*}{$\begin{array}{c}\text { Concentration } \\
\text { of amino acids } \% \\
\text { (factor A) }\end{array}$} & $\begin{array}{c}\text { Stem elongation stage } \\
\text { BBCH 32-35 }\end{array}$ & $\begin{array}{c}\text { Heading stage } \\
\text { BBCH 51-56 }\end{array}$ \\
\cline { 2 - 3 } & $13.0 \mathrm{a}$ & $13.2 \mathrm{a}$ \\
\hline Control (without amino acids) & $13.5 \mathrm{ab}$ & $14.0 \mathrm{bc}$ \\
\hline Amino acids 0.5\% & $13.4 \mathrm{a}$ & $14.0 \mathrm{bc}$ \\
\hline Amino acids 1.0\% & $13.6 \mathrm{~b}$ & $14.1 \mathrm{c}$ \\
\hline Amino acids 1.5\% & $13.8 \mathrm{~b}$ & $13.8 \mathrm{~b}$ \\
\hline Amino acids 2.0\% & $13.8 \mathrm{~b}$ & $13.5 \mathrm{ab}$ \\
\hline Amino acids 2.5\% & $13.6 \mathrm{~b}$ & $13.6 \mathrm{~b}$ \\
\hline Amino acids 3.0\% & & \\
\hline
\end{tabular}

Note. Values followed by the same letters are not significantly different $(P>0.05)$ 
The correlation regression data analysis suggested that the relationship between grain protein content and amino acids concentrations in fertilizer at stem elongation stage was best reflected by the linear regression equation $\mathrm{y}_{1}=13.2464+0.1859 \mathrm{x}$.

The data evidenced that having foliar applied amino acids solution at winter wheat heading stage the grain accumulated the highest amino acids contents, which were by on average $2.7 \%$ higher compared with the treatments applied with the same fertilizers at stem elongation stage (Table 2). A significant increase in amino acids content in wheat grain was recorded having fertilized at heading stage with $0.5,1.0,1.5$ and $3.0 \%$ concentrations of amino acids solution, compared with the control. The highest amino acids content $\left(134.1 \mathrm{~g} \mathrm{~kg}^{-1}\right)$ at this stage was accumulated by winter wheat fertilized with the lowest $(0.5 \%)$ amino acids concentration solution. It is likely that the lowest amino acids concentrations had the least effect on the imbalance of amino acids present in plant proteins, and therefore the highest amino acids content was accumulated in grain, since the period from fertilizer application until grain maturity was shorter, compared with the application at stem elongation stage. The correlation regression analysis of the experimental data revealed a significant $(\mathrm{P}<0.05)$ and strong $\left(\mathrm{r}=0.78^{*}\right)$ linear correlation $\mathrm{y}=121.5418$ $+2.1346 \mathrm{x}$ between the total amino acids content in grain and amino acids concentration in fertilizer (BBCH 32-35).

Foliar spraying with amino acids rapidly corrects nutrients deficiencies due to its being readily absorbed and directly utilized to synthesis proteins (Kandil et al., 2016). Popko and colleagues (2018) reported too, that amino acids had shown a positive effect on winter wheat yield and protein content in grains.

Table 2. The effect of amino acids applied at winter wheat on the total amount of amino acids $\left(\mathrm{g} \mathrm{kg}^{-1}\right)$ in winter wheat grain

\begin{tabular}{|c|c|c|}
\hline \multirow{2}{*}{$\begin{array}{l}\text { Concentration } \\
\text { of amino acids \% } \\
\text { (factor A) }\end{array}$} & \multicolumn{2}{|c|}{ Fertilization timing (factor B) } \\
\hline & $\begin{array}{c}\text { Stem elongation stage } \\
\text { BBCH 32-35 }\end{array}$ & $\begin{array}{l}\text { Heading stage } \\
\text { BBCH 51-56 }\end{array}$ \\
\hline Control (without amino acids) & $123.0 \mathrm{a}$ & $123.1 \mathrm{a}$ \\
\hline Amino acids $0.5 \%$ & $121.0 \mathrm{a}$ & $134.1 \mathrm{c}$ \\
\hline Amino acids $1.0 \%$ & $124.2 \mathrm{a}$ & $130.6 \mathrm{bc}$ \\
\hline Amino acids $1.5 \%$ & $125.1 \mathrm{a}$ & $129.7 \mathrm{~b}$ \\
\hline Amino acids $2.0 \%$ & $122.6 \mathrm{a}$ & $123.4 \mathrm{a}$ \\
\hline Amino acids $2.5 \%$ & $128.8 \mathrm{~b}$ & $123.9 \mathrm{a}$ \\
\hline Amino acids $3.0 \%$ & $128.4 \mathrm{~b}$ & $128.9 \mathrm{~b}$ \\
\hline
\end{tabular}

Note. Values followed by the same letters are not significantly different $(P>0.05)$

The analysis of nonessential amino acids in the winter wheat grain indicated that their content depended on the concentration of amino acids in the fertilizer when the crop was fertilized at stem elongation stage (Table 3). The significantly highest contents of amino acids in winter wheat grain were accumulated in the treatments at stem elongation stage fertilized with 2.5 and $3.0 \%$ concentrations of amino acids. The lowest contents of these amino acids were accumulated in the treatments fertilized with $0.5 \%$ amino acids solution. The distribution of data was best described by a linear regression equation $\mathrm{y}=89.7708+1.4707 \mathrm{x}\left(\mathrm{r}=0.76^{*}\right)$, which showed that with $1.0 \%$ increase in amino acids concentration in the fertilizer, the total amino acids content in winter wheat grain increased by $1.47 \mathrm{~g} \mathrm{~kg}^{-1}$.

Solutions of different concentrations of amino acids used at the heading stage also increased the content of nonessential amino acids in winter wheat grain (Table 3). A significantly higher content of nonessential amino acids was accumulated in the grain of wheat fertilized at this stage with $0.5,1.0,1.5 \%$ concentrations of amino acids. The published data suggests that amino acids are able to stimulate carbon and nitrogen metabolism and therefor nitrogen assimilation could be increasing (Liang et al., 2013; Calvo et al., 2014).

Table 3. The effect of amino acids applied at winter wheat on the nonessential amino acids amount $\left(\mathrm{g} \mathrm{kg}^{-1}\right)$ in winter wheat grain

\begin{tabular}{|c|c|c|}
\hline \multirow{2}{*}{$\begin{array}{c}\text { Concentration } \\
\text { of amino acids \% } \\
(\text { factor } \mathrm{A})\end{array}$} & \multicolumn{2}{|c|}{ Fertilization timing (factor B) } \\
\hline & $\begin{array}{c}\text { Stem elongation stage } \\
\text { BBCH 32-35 } \\
\end{array}$ & $\begin{array}{l}\text { Heading stage } \\
\text { BBCH 51-56 } \\
\end{array}$ \\
\hline Control (without amino acids) & $90.7 \mathrm{a}$ & $90.7 \mathrm{a}$ \\
\hline Amino acids $0.5 \%$ & $89.3 \mathrm{a}$ & $98.6 \mathrm{c}$ \\
\hline Amino acids $1.0 \%$ & $91.7 \mathrm{ab}$ & $95.5 \mathrm{bc}$ \\
\hline Amino acids $1.5 \%$ & $92.7 \mathrm{ab}$ & $95.6 \mathrm{~b}$ \\
\hline Amino acids $2.0 \%$ & $90.3 \mathrm{a}$ & $90.4 \mathrm{a}$ \\
\hline Amino acids $2.5 \%$ & $94.9 \mathrm{~b}$ & $90.8 \mathrm{a}$ \\
\hline Amino acids $3.0 \%$ & $94.3 \mathrm{~b}$ & $90.8 \mathrm{a}$ \\
\hline
\end{tabular}

Note. Values followed the same letters are not significantly different $(P>0.05)$

A qualitative analysis of nonessential amino acids (Figure 1) revealed that fertilizer with $2.5 \%$ amino acids solution significantly increased the contents of aspartic $\left(0.24 \mathrm{~g} \mathrm{~kg}^{-1}\right)$, glutamic $\left(2.39 \mathrm{~g} \mathrm{~kg}^{-1}\right)$, proline $\left(0.61 \mathrm{~g} \mathrm{~kg}^{-1}\right)$, arginine $(0.50$ $\left.\mathrm{g} \mathrm{kg}^{-1}\right)$ and alanine $\left(0.22 \mathrm{~g} \mathrm{~kg}^{-1}\right)$ acids in winter wheat grain, when the crop was fertilized at stem elongation stage. Having used $3.0 \%$ amino acids solution, a significant increase occurred in the contents of glutamic $\left(2.21 \mathrm{~g} \mathrm{~kg}^{-1}\right)$ and alanine $(0.34$ $\left.\mathrm{g} \mathrm{kg}^{-1}\right)$ acids in grain. Glutamic acid $\left(1.73 \mathrm{~g} \mathrm{~kg}^{-1}\right)$ and proline acid $\left(0.61 \mathrm{~g} \mathrm{~kg}^{-1}\right)$ contents were significantly increased also by $1.5 \%$ concentration of amino acids solution. When amino acids fertilizers had been used at stem elongation stage, very strong, strong and moderately strong relationships were established between amino acids concentrations in fertilizer and contents of glutamic, alanine, aspartic and histidine acids in grain (Table 4). The relationship of the above-mentioned indicators was best represented by the regression equations of the first and second degree. Since glutamic acid is a main 
source for other amino acids synthesis (Taiz and Zeiger, 2010; Ertani et al., 2013; Colla et al., 2015), a correlation regression analysis was done on the data of glutamic and nonessential amino acids. The distribution of data was best reflected by the linear regression equation $y=9.065+0.9508 x$, and the relationship was significant and strong $(r=0.89 *)$.

Table 4. Relationship between the concentration of the amino acids in the solution $(0.5<x>3.0, \%)$ and nonessential amino acids content $\left(\mathrm{y}, \mathrm{g} \mathrm{kg}^{-1}\right)$ in winter wheat grain when foliar applied at stem elongation stage

\begin{tabular}{|c|c|c|}
\hline$y$ & Regression equation & Correlation coefficient \\
\hline Glutamic & $\mathrm{y}=41.2877+0.8094 \mathrm{x}_{1}$ & $\mathrm{r}=0.84^{*}$ \\
\hline Alanine & $\mathrm{y}=4.6503+0.1285 \mathrm{x}_{2}$ & $\mathrm{r}=0.81^{*}$ \\
\hline Aspartic & $\mathrm{y}=5.6646+0.0797 \mathrm{x}_{3} ;$ & $\mathrm{r}=0.69^{*}$ \\
\hline Histidine & $\mathrm{y}=4.2003-0.2534 \mathrm{x}_{4}+0.1113 \mathrm{x}_{4}{ }^{2}$ & $\mathrm{r}=0.91^{*}$ \\
\hline
\end{tabular}

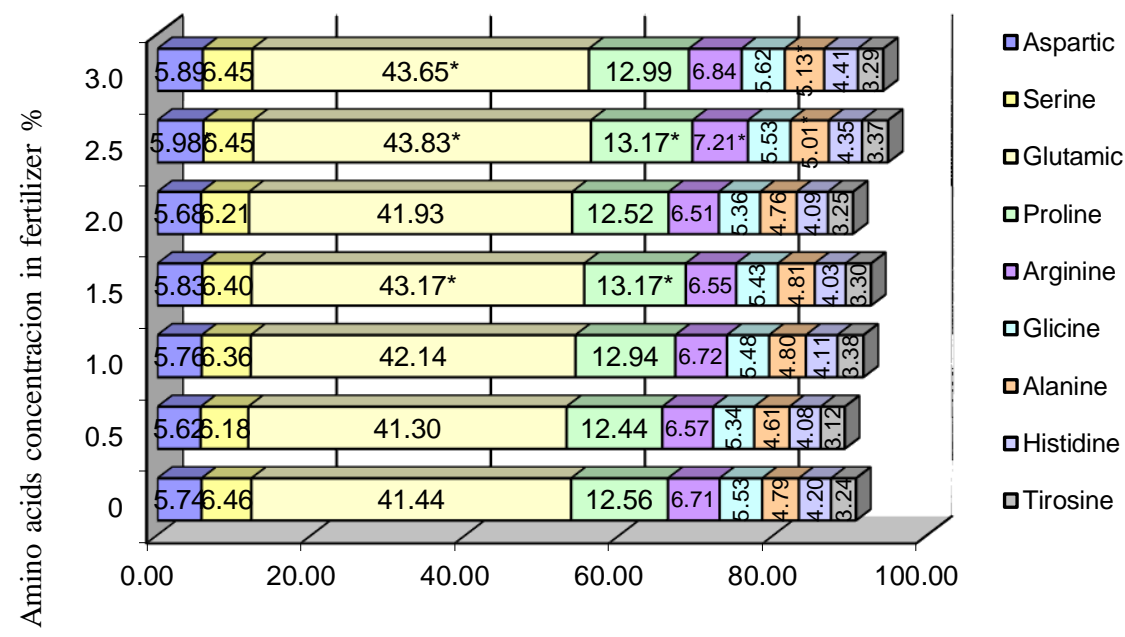

Note. $*_{\text {- significant at } P<0.05}$

Nonessential amino acids content $\mathrm{g} \mathrm{kg}^{-1}$

Figure 1. The effect of different concentration of amino acids on the content of nonessential amino acids $\left(\mathrm{g} \mathrm{kg}^{-1}\right)$ in winter wheat grain (foliar fertilized at $\mathrm{BBCH} 32-35$ stage)

Analysis of the contents of individual nonessential acids in winter wheat grain revealed that at heading stage the lowest amino acids concentration $(0.5 \%)$ had the greatest impact on the content of nonessential amino acids in grain (Figure 2). Fertilization with the above-mentioned concentrations of amino acids gave an increase in the contents of aspartic, serine, glutamic, proline, arginine, glycine, histidine, alanine and tyrosine in winter wheat grain. It is noteworthy that fertilizers with $0.5,1.0,1.5$ and $3.0 \%$ amino acids concentrations applied at heading stage had a particularly positive effect on glutamic acid content, which increased by $2.21-4.29 \mathrm{~g} \mathrm{~kg}^{-1}$, respectively, compared with the control treatment. The relationship between nonessential amino acids content and glutamic acid content was statistically significantly described by the linear equation $\mathrm{y}=6.4288+1.0168 \mathrm{x} ; \mathrm{r}=0.96^{*}$.

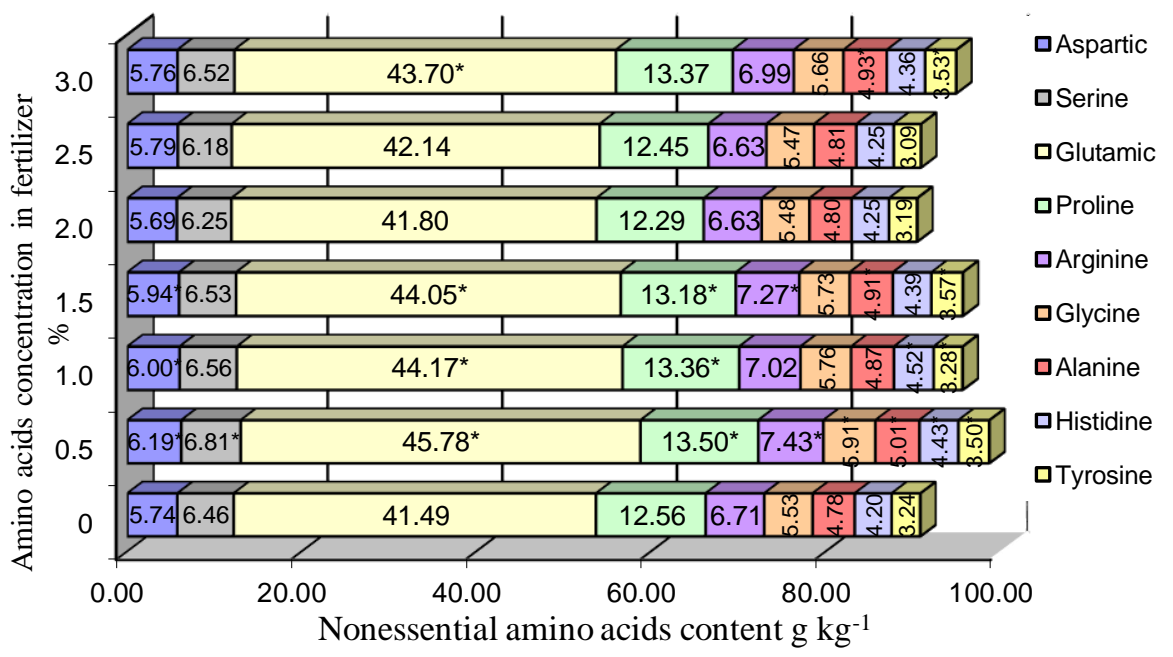

Note. * - significant at $P<0.05$

Figure 2. The effect of different concentration of amino acids on the content of nonessential amino acids $\left(\mathrm{g} \mathrm{kg}^{-1}\right)$ in winter wheat grain (foliar fertilized at BBCH 51-56 stage) 
The nutritional value of proteins is characterised by the value of essential amino acids (Tegeder and Rentsch, 2010; Taiz and Zeiger, 2010). The data of our study suggest that the content of essential amino acids accumulated in winter wheat grain reflected the trends of variation of total and nonessential amino acids contents (Table 5). When winter wheat had been fertilized at stem elongation stage with 2.5 and $3.0 \%$ amino acids solutions, significantly the highest contents of essential amino acids in grain were obtained. The lowest amino acids content in grain was established in the plots fertilized with $0.5 \%$ amino acids solution. The correlation regression analysis between amino acids concentrations in fertilizer and essential amino acids content in grain evidenced that with increasing amino acids concentration in fertilizer the content of essential amino acids in grain also increases, $y=31.7709+0.6639 x,\left(r=0.80^{*}\right)$.

The analysis of data of individual essential amino acids revealed that the use of $2.5 \%$ amino acids concentration solution (foliar fertilized BBCH 32-35 stage) significantly effected on the content of valine, leucine, phenylalanine and methionine in grain (Figure 3). The highest concentration of amino acids (3.0\%) gave the highest increase in the content of threonine, valine, isoleucine, leucine and phenylalanine in wheat grain. It is likely that the period from fertilization with amino acids to grain formation was rather long, therefore higher concentrations of amino acids (2.5 and 3.0\%) present in fertilizers had a greater impact on the synthesis of essential amino acids in grain. Strong correlations were found between amino acids concentrations applied at stem elongation stage and individual essential amino acids: valine $\left(\mathrm{r}=0.76^{*}\right)$; leucine $\left(\mathrm{r}=0.80^{*}\right)$; phenylalanine $\left(\mathrm{r}=0.74^{*}\right)$ in grain.

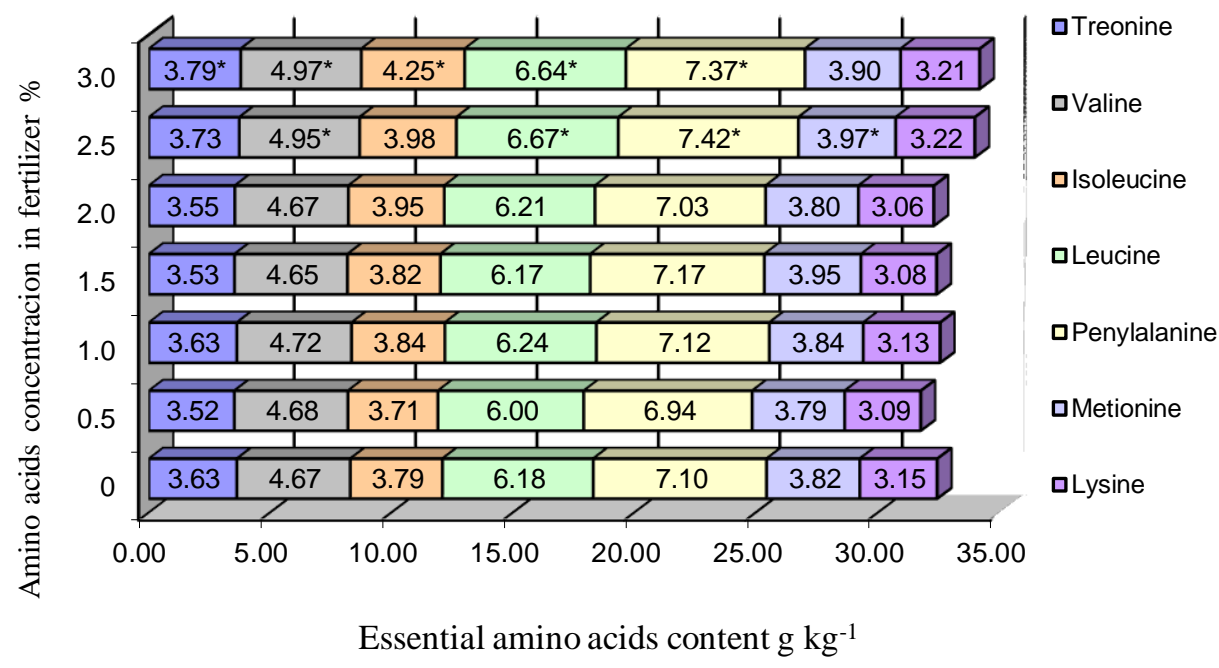

Note. *- significant at $P<0.05$

Figure 3. The effect of different concentration of amino acids on the content of essential amino acids ( $\left.\mathrm{g} \mathrm{kg}^{-1}\right)$ in winter wheat grain (foliar fertilized at BBCH 32-35 stage)

Solutions of $0.5,1.0,1.5$, and $3.0 \%$ concentrations of amino acids used at heading stage significantly increasing the content of essential amino acids in grain (Table 5). Analysis of the qualitative composition of essential amino acids in grain showed that amino acids sprayed on winter wheat leaves at heading stage resulted in the highest essential amino acids contents in grain, which were by on average $3.9 \%$ and $7.2 \%$ higher, than sprayed with the same fertilizers at stem elongation stage. It was also found that the content of essential amino acids in grain depended on glutamic acid content, $y=3.4029+0.7045 \mathrm{x} ; \mathrm{r}=$ $0.97^{*}$. Analysis of the composition of individual essential amino acids suggested that $0.5 \%$ amino acids solution foliar-applied at heading stage significantly increased valine, isoleucine, leucine, phenylalanine, methionine and lysine contents, while $1.0 \%$ concentration solution increased the contents of valine, isoleucine, leucine,methionine, and lysine in winter wheat grain (Figure 4). The solution with the highest concentration of amino acids (3.0\%) significantly increased the contents of leucine and methionine in grain. Solutions of $0.5-1.5 \%$ amino acids concentrations foliar-applied at heading stage significantly increased lysine content in wheat grain and, at the same time, improved the biological value of proteins. In the winter wheat is a little content of lysine (Shewry, 2007; Millward, 2012; Khan et al., 2014).

Table 5. The effect of liquid amide nitrogen fertilizers containing amino acids applied at winter wheat on the amount $\left(\mathrm{g} \mathrm{kg}^{-1}\right)$ of essential amino acids in winter wheat grain

\begin{tabular}{|l|c|c|}
\hline \multicolumn{1}{|c|}{$\begin{array}{c}\text { Concentration } \\
\text { of amino acids } \\
\text { (factor A) }\end{array}$} & \multicolumn{2}{|c|}{ Fertilization timing (factor B) } \\
\cline { 2 - 3 } & $\begin{array}{c}\text { Stem elongation stage } \\
\text { BBCH 32-35 }\end{array}$ & $\begin{array}{c}\text { Heading stage } \\
\text { BBCH 51-56 }\end{array}$ \\
\hline Control (without amino acids) & $32.4 \mathrm{a}$ & $32.4 \mathrm{a}$ \\
\hline Amino acids 0.5\% & $31.7 \mathrm{a}$ & $35.6 \mathrm{c}$ \\
\hline Amino acids 1.0\% & $32.5 \mathrm{a}$ & $35.1 \mathrm{~b}$ \\
\hline Amino acids 1.5\% & $32.4 \mathrm{a}$ & $34.1 \mathrm{bc}$ \\
\hline Amino acids 2.0\% & $32.3 \mathrm{a}$ & $33.1 \mathrm{a}$ \\
\hline Amino acids 2.5\% & $33.9 \mathrm{~b}$ & $33.1 \mathrm{a}$ \\
\hline Amino acids 3.0\% & $34.1 \mathrm{~b}$ & $34.1 \mathrm{bc}$ \\
\hline
\end{tabular}

Note. Values followed the same letters are not significantly different $(P>0.05)$ 


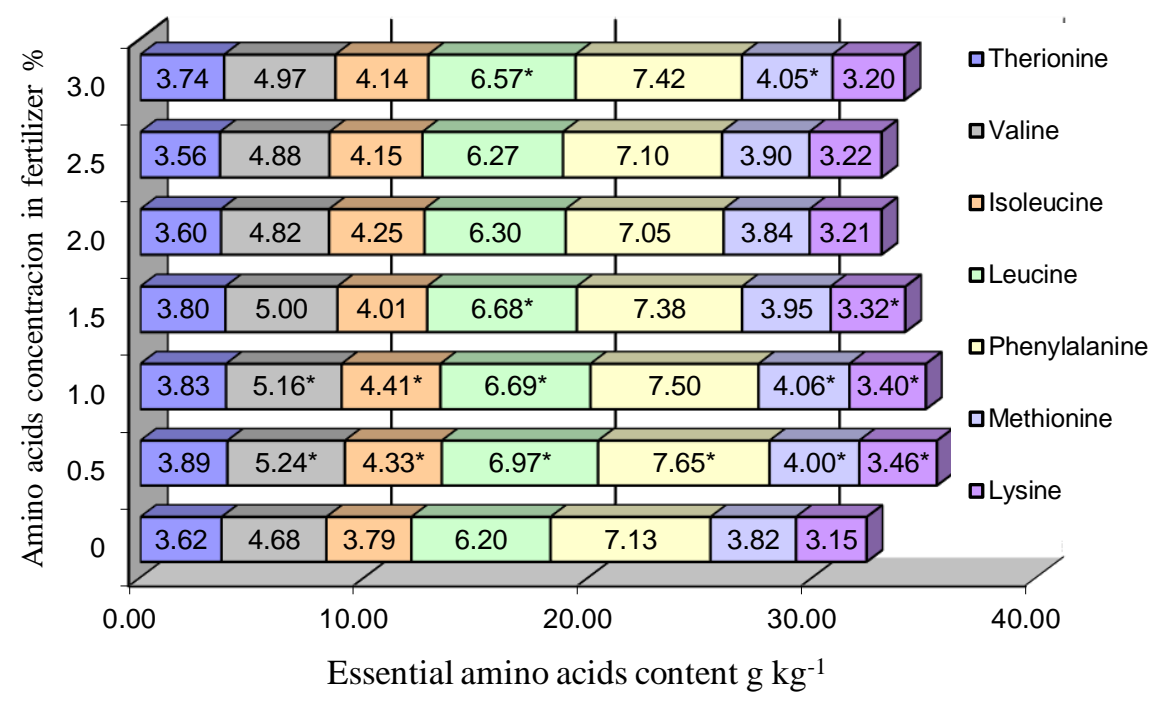

Note. * - significant at $P<0.05$

Figure 4. The effect of different concentrations of amino acids on the content of essential amino acids $\left(\mathrm{g} \mathrm{kg}^{-1}\right)$ in winter wheat grain (foliar fertilized at BBCH 51-56 stage)

In summary, it can be asserted that winter wheat additional fertilization with liquid fertilizers with amino acids at stem elongation and heading stages resulted higher protein content in grain. The statistical analysis of the experimental data $\left(\mathrm{x}_{\text {extr. }}\right)$ shows that in order to produce grain with the highest protein content, it is expedient to fertilize winter wheat crops with $1.5 \%$ concentration of amino acids solution at heading stage.

The positive effect of liquid fertilizers with amino acids was established on the accumulation of both nonessential and essential amino acids in winter wheat grain. The increase in the nutritional value of proteins was mostly influenced by application of amino acids at heading stage. Significant increase was determined when fertilizing with the solutions of amino acids at $0.5,1.0,1.5$ and $3.0 \%$ concentrations.

\section{CONCLUSIONS}

Amino acids increased protein and total amino acids contents in winter wheat grain. Plants, fertilized with the solutions of amino acids at stem elongation stage accumulated on average $4.8 \%$ higher protein content, at heading stage by $4.5 \%$ compared with the grain protein content of plants that had not received amino acids fertilization. The total amino acids content in winter wheat grain in response to amino acids applied at stem elongation stage increased by on average $2.0 \mathrm{~g} \mathrm{~kg}^{-1}$, at heading stage by $5.3 \mathrm{~g} \mathrm{~kg}^{-1}$. Nonessential and essential amino acids content in winter wheat grain was significantly increased by 2.5 and $3.0 \%$ amino acids solutions applied at stem elongation stage; by $0.5,1.0,1.5 \%$ amino acids solutions applied at heading stage. Winter wheat fertilization with amino acids solutions at heading stage mostly increased glutamic, aspartic, valine, isoleucine, leucine, phenylalanine, methionine, threonine and lysine acids content, at stem elongation stage - glutamic acid content.

\section{REFERENCES}

1. Azimi M.S, Daneshian J., Sayfzadeh S., Zare S. 2013. Evaluation of Amino Acid and Salicylic Acid application on yield and growth of wheat under water deficit. Journal of Agronomy and Crop Science, Vol. 5, pp. 816-819.

2. Calvo P., Nelson L., Kloepper J. W. 2014. Agricultural uses of plant biostimulants. Journal. Plant and Soil, Vol. 383, pp. 3-41. https://doi.org/10.1007/s11104-014-2131-8

3. Colla G., Nardi S., Cardarelli M., Ertani A., Lucini L., Canaguier R., Rouphael Y. 2015. Protein hydrolysates as biostimulants in horticulture. Journal. Horticultural Science, Vol. 196, pp. 28-38. https://doi.org/10.1016/j.scienta.2015.08.037

4. De Lucia B., Vecchietti L. 2012. Type of bio-stimulant and application method effects on stem quality and root system growth in L.A. Lily. Journal Horticultural Science, Vol. 77,pp. 10-15.

5. Du Jardin P. 2015. Plant biostimulants: Definition, concept, main categories and regulation. Journal Horticultural Science Vol. 196, pp. 3-14. https://doi.org/10.1016/j.scienta.2015.09.021

6. Ertani A., Schiavon M., Muscolo A., Nardi S. 2013. Alfalfa plant-derived biostimulant stimulate short-term growth of salt stressed Zea mays L. plants. Journal Plant and Soil, Vol. 364, pp. 145-158. https://doi.org/10.1007/s11104-012-1335-Z

7. Friedman M. 1996. Nutritional Value of Proteins from Different Food Sources. A Review. Journal of Agricultural and Food Chemistry, Vol. 44, pp. 6-29. https://doi.org/10.1021/jf9400167

8. Galili G., Amir R. 2013. Fortifying plants with the essential amino acids lysine and methionine to improve nutritional quality. Journal Plant Biotechnology, Vol. 11, pp. 211-222. https://doi.org/10.1111/pbi.12025 
9. Hill T., Levicki P. 2005. Statistics methods and applications. Madison, USA, pp. 800.

10. IUSS Working Group WRB 2014. World Reference Base for Soil Resources 2014. International Soil Classification System for Naming Soils and Creating Legends for Soil Maps. World Soil Resources Reports No. 106. FAO, Rome.

11. Kandil A.A., Sharief A.E.M., Seadh S.E., Altai D. S.K. 2016. Role of humic acid and amino acids in limiting loss of nitrogen fertilizer and increasing productivity of some wheat cultivars grown under newly reclaimed sandy soil. Int. International Journal of Advanced Research in Biological Sciences, Vol. 3, pp. 123-136.

12. Khan M.S., Ali E., Ali S., Khan W.M., Sajjad M.A., Hussain F. 2014. Assessment of essential amino acids in wheat proteins: a case study. J Journal of Biodiversity and Environmental Sciences, Vol. 4, pp. 185-189.

13. Le D.T., Chu H.D., Le N.Q. 2016. Improving Nutritional Quality of Plant Proteins Through Genetic Engineering. Journal Current Genomics, Vol. 17, pp. 220-229. https://doi.org/10.2174/1389202917666160202215934

14. Liang X., Zhang L., Natarajan S.K., Beckker D.F. 2013. Proline mechanisms of stress survival. Antioxidants \& Redox Signaling, Vol. 19, pp. 998-1011. https://doi.org/10.1089/ars.2012.5074

15. Mendes R.T., Resende R.C., Moreira Pereira M.A., Bento R.U., Dias da Silva R.C., Cruz S.J., Pelá A. 2016. Foliar application of urea and bell pepper amino acids. African Journal of Agricultural Research, Vol. 11, pp. 1674-1678. https://doi.org/10.5897/AJAR2015.10496

16. Millward D.J. 2012. Amino acid scoring patterns for protein quality assessment. British Journal of Nutrition, Vol. 108, pp. $31-43$. https://doi.org/10.1017/S0007114512002462

17. Nuttall J.G., O’Leary G.J., Panozzo J.F., Walker C.K., Barlow K.M., Fitzgerald G.J. 2017. Models of grain quality in wheat - A review. Journal Field Crops Research, Vol. 202, pp. 136-145. https://doi.org/10.1016/j.fcr.2015.12.011

18. Penas E., Martinez-Villaluenga C., Vidal-Casero C., Zielinski H., Frias J. 2013. Protein Quality of Traditional Rye Breads and Ginger Cakes as Affected by the Incorporation of Flour with Different Extraction Rates. Polish Journal of Food and Nutrition Sciences, Vol. 63, pp. 5-10. https://doi.org/10.2478/v10222-012-0067-3

19. Popko M., Michalak I., Wilk R., Gramza M., Chojnacka K., Górecki H. 2018. Effect of the new plant growth biostimulants based on amino acids on yield and grain quality of winter wheat. Journal Molecules, Vol. $23, \quad$ pp. 470. https://doi.org/10.3390/molecules23020470

20. Sadak S.H. M., Abdelhamid M.T., Schmidhalter U. 2015. Effect of foliar application of amino acids on plant yield and physiological parameters in bean plants irrigated with seawater. Journal Acta Biológica Colombiana, Vol. 20, pp. 141-152.

21. Shewry P.R. 2007. Improving the protein content and composition of cereal grain. Journal of Cereal Science, Vol. 46, pp. 239-250. https://doi.org/10.1016/j.jcs.2007.06.006

22. Taiz L. and Zeiger E. 2010. Plant Physiology. 5th Edition, Sinauer Associates Inc., Sunderland, pp. 782.

23. Tegeder M., Rentsch D. 2010. Uptake and partitioning of amino acids and peptides. Journal Molecular Plant, Vol. 3, pp. 997-1011. https://doi.org/10.1093/mp/ssq047

24. Wang G., Xu M., Wang W., Galili G. 2017. Fortifying Horticultural Crops with Essential Amino Acids: A Review. International Journal of Molecular Sciences, Vol. 18, pp. 1306. https://doi.org/10.3390/ijms 18061306

25. Zhu C.F., Naqvi S., Gomez S.G., Pelacho A.M., Capell T., Christou P. 2010. Vitamin, protein and essential mineral enhancement of cereal crops for food security. Journal GMO Biosafety Research, Vol. 1, pp. 315-318.

https://doi.org/10.5376/gmo.2010.01.0002 